\title{
Cartas: um acervo de memória afetiva e histórica e a importância de sua
}

preservação

\author{
Nicole Marinho Horta ${ }^{1}$ \\ Débora de Almeida Dias ${ }^{2}$ \\ Luciana Coutinho Cordeiro ${ }^{3}$
}

Resumo: O papel das cartas no desenvolvimento da comunicação como fonte informacional para além de sua propriedade como fonte biográfica; as potencialidades do seu estudo e o valor de sua conservação, classificação e a disseminação das informações nelas contidas são temas desse artigo. Para evidenciá-los foram desenvolvidas: uma entrevista com uma bibliotecária conhecedora do acervo do musicólogo alemão radicado no Uruguai, Francisco Curt Lange depositado na Biblioteca Universitária (BU) da Universidade Federal de Minas Gerais (UFMG) e a análise documental de parte desse mesmo acervo. A análise teve como foco a série " 2 Correspondência”, que contém cópias das cartas enviadas por ele e cartas originais recebidas de terceiros que tratam de assuntos variados. No trabalho, são discutidos conceitos que se situam entre as áreas da arquivologia, biblioteconomia e museologia, temas como: acervos pessoais, classificação, preservação e, também, a importância dos profissionais da área da ciência da informação facilitadores do acesso às informações contidas nesse tipo de documento. Finalmente é destacada a problemática da preservação e conservação desses documentos que, embora não sejam oficiais, são ricas fontes de informações sobre o contexto histórico e, justamente por isso, são objeto de estudo de diversas áreas.

Palavras-chave: Acervo pessoais. Cartas. Francisco Curt Lange. Preservação.

\section{Letters: a collection of affective and historical memories and the importance of their preservation}

\begin{abstract}
The role of letters in the development of communication as an informational source beyond its condition as a biographical source; the potentialities of its study and the value of its conservation, classification and the dissemination of the information contained in it are themes of this article. This work was developed through an interview with a librarian familiarised with a collection of the Brazilian musicologist living in Uruguay, Francisco Curt Lange - under the custody of the University Library (BU) of the Federal University of Minas Gerais (UFMG) - and a documentary analysis of part of this acquis. The analysis focused on the series "2 -

\footnotetext{
${ }^{1}$ Bacharel e licenciada em história - Uni-BH, especialista em mídias na educação - UFOP. Graduanda em biblioteconomia - UFMG. Estagiária na biblioteca da Faculdade de Filosofia e Ciências Humanas - FAFICH da UFMG. E-mail: nicole_coia@yahoo.com.br.

${ }^{2}$ Graduanda em Biblioteconomia pela UFMG. E-mail: dias.debora87@gmail.com.

${ }^{3}$ Graduada em Letras - Centro Federal de Educação Tecnológica de Minas Gerais. Graduanda em Biblioteconomia pela UFMG. E-mail: lucianaccordeiro@gmail.com.
} 
Correspondence", which contains copies of the letters sent by him and original letters received from third parties dealing with various subjects. In this work, were discussed concepts located between the areas of archivology, librarianship and museology. Themes such personal collections, classification, preservation and also the importance of professionals in the area of information Science in its role of facilitators of access to information contained in this type of document were approached. Finally, the problem of the preservation and conservation of these documents, that although they are not official are very important, was highlighted. It was considered in this reflection the fact that the letters were a rich source of information about the historical contextextes and, precisely for this reason, they are object of study of several areas.

Key words: Personal Collection. Letters. Francisco Curt Lange. Preservation.

\section{INTRODUÇÃO}

Os vestígios mais antigos de escrita são do século IV a.C., da região da baixa Mesopotâmia e foram um marco para a história da humanidade. A primeira escrita surgiu em forma de ideogramas, que representavam palavras, passando a adquirir valores fonéticos, diminuindo a quantidade de signos. A escrita evoluiu e os fenícios criaram o primeiro alfabeto contendo apenas consoantes. Os gregos usaram a base do alfabeto fenício e criaram um novo alfabeto acrescentando vogais; este alfabeto deu origem ao alfabeto etrusco que posteriormente se torna o alfabeto latino, Gomes (2007) descreve a importância do Império Romano para a difusão do Latim no território europeu. Através da miscigenação dos povos, a imposição do latim durante o Império Romano, fizeram que outras línguas surgissem, como o Italiano, o Francês, o Espanhol, o Catalão, o Galego, o Português, o Romeno.

A escrita evoluiu e, com ela, os meios de comunicação também. O meio de comunicação escrita "cartas/correspondências", será analisado observando a conceituação de Rolf Nagel (1989) que esclareceu o que esses meios são:

\section{Carta:}

1 - Carta mensagem escrita endereçada a uma pessoa pública ou privada em envelope por via Postal.

2 - Credencial conferindo poderes ou concedendo determinados privilégios.

Correspondência: Toda forma de comunicação escrita, expedida (ativa) ou recebida (passiva) por pessoas físicas ou jurídicas, sob várias formas (ofício, circular, memorando, telegrama, cartas, cartões-postais, bilhetes, notas, telegramas e outros), podemos ser oficial ou particular, ostensiva ou sigilosa (NAGEL, 1989, p.60).

As cartas são utilizadas como forma direta de comunicação, tendo assim dois sujeitos: o emissor e o receptor. Há registro da prática epistolar desde a antiguidade, mas foi no século 
XVIII que este hábito tornou-se costumeiro, sendo, porém, ainda uma prática aristocrática, como Teresa Malation descreve:

A partir do século XVIII, as cartas adquiriram papel cada vez mais relevante para a expressão de sentimentos, emoções e experiências. O hábito da correspondência tornouse mais difundido, alcançou diversas camadas sociais e constituiu-se em prática cultural bastante apreciada tanto na Europa como na América (MALATION, 2009, p.196).

No Brasil essa prática intensificou-se no século XIX. Como Salamon (2010) afirma, em 1850, com o crescimento de imigrantes no território nacional a troca de cartas tornou-se necessária, como única forma de comunicação com os seus, que permaneciam nos países de origem. Já o processo de utilização das cartas como fontes de informação ocorre em meados do século XIX, por meio de profissionais como historiadores, sociólogos e antropólogos, que tratam a correspondência como documento, fonte de informação repleta de informações culturais, políticas e sociais.

As cartas serão assim trabalhadas como fonte documental, e estes documentos são de origem de arquivos pessoais. Baumann (2011) expõe a importância destes arquivos pessoais e de família como fonte de pesquisa singular:

Os arquivos pessoais e de família representam uma fonte de pesquisa única capaz de interagir com estruturas comunicacionais de um indivíduo e sua relação com o mundo. Os avanços de estudos teóricos e metodológicos da arquivologia sobre os arquivos pessoais transformaram esses conjuntos documentais em preciosos repositórios informacionais para pesquisadores, que a cada dia se debruçam sobre o estudo de documentos de personalidades do mundo da cultura, da filosofia e das artes (BAUMANN, 2011, p.24).

Analisa-se que as cartas (e os arquivos pessoais) sendo consideradas como fonte documental, permitiram o acesso informacional a fatos que articulavam o ponto de vista pessoal com os acontecimentos sociais e políticos relacionados em seu contexto histórico. Para elucidar o panorama das cartas como fonte documental e a importância deste tipo de acervo, será analisada neste artigo a série "2 - Correspondência" com as subséries "2.1 - Correspondência Enviada" e "2.2 - Correspondência Recebida”, do acervo de cartas de Francisco Curt Lange, que desde 1995 integra o Acervo Curt Lange da Biblioteca Universitária - BU, da Universidade Federal de Minas Gerais (UFMG). Será descrito o recolhimento pela universidade, os processos de tratamento e conservação, o acesso ao acervo e a importância desta coleção como fonte informacional.

\section{CARTAS: FONTE INFORMACIONAL E A SUA POLÍTICA DE PRESERVAÇÃO}

Múltiplos Olhares em Ciência da Informação, v.8, n.1, mar. 2018. 
As cartas, por serem um meio de comunicação utilizado por diferentes agentes sociais, tratam de assuntos diversificados, podendo conter fatos históricos como: a Carta de Pero Vaz de Caminha endereçada a Dom Manoel, então Rei de Portugal em 1500, descrevendo a terra que acabara de descobrir, que hoje faz parte do acervo do Arquivo Nacional da Torre do Tombo, em Lisboa (Portugal). E as Cartas de Amarna, que contabilizam 379 cartas, trocadas entre o faraó egípcios e reis de Estados da Mesopotâmia, escritas em tábuas de argila no século XIV a.C., que fazem parte dos acervos do Museu do Louvre em Paris, Museu Egípcio no Cairo, Museu Britânico em Londres e do Vorderasiatischen Museum em Berlim. Estes são grandes exemplos, mas não são os únicos, sendo possível que as cartas tornem-se objetos de estudos, descrevendo circunstâncias do cotidiano, culturas, costumes e fatos políticos, Malation (2009) descreve que fontes informacionais como as cartas são fontes informacionais primárias passíveis de estudo como documentos dos períodos no qual foram produzidas.

As epístolas tornam-se importantes, no século XX, como documentos de sua época. Roger Chartier (2009, p. 218) descreve a igualdade de importância das cartas em relação aos demais objetos históricos: "Evidentemente, os autorretratos, os retratos, bem como as cartas, as autobiografias, os diários e as memórias, são objetos-relíquia tanto quanto os pentes e os anéis”. Dentro da historiografia, Teresa Malation descreve a modificação do uso das cartas, não somente como fonte de informação, mas também um objeto de estudo repleto de recursos históricos:

A valorização da experiência individual pela historiografia tem levado os historiadores ao interesse pelas cartas como objeto de investigação em lugar de considerá-las apenas fontes de informação as múltiplas possibilidades de sua abordagem e utilização seja como fonte seja como objeto inevitavelmente encontraram no caminho a especificidades do gênero epistolar (MALATION, 2009. p. 203).

A documentação como fonte informacional e de pesquisa possui uma ampla gama de conceituação, sendo que no campo da Ciência da Informação, Paul Otlet conceitua documento e a documentação da seguinte forma:

Documento é o livro, a revista, o jornal, é a peça de arquivo, a estampa, a fotografia, a medalha, a música, é também atualmente o filme, o disco e toda a parte documental que precede ou sucede a emissão radiofônica. Ao lado dos textos e imagens há objetos documentais por si mesmos (OTLET, 1937, p.1).

De acordo com Tanus, Renau e Araújo (2012), no campo da arquivologia, podemos encontrar uma certa restrição no conceito de documento arquivístico, tendo este algumas peculiaridades, inclusive a ideia de que deve haver neles uma natureza administrativa, entretanto, 
sabendo da multiplicidade dos conceitos e tendo as cartas como elemento de informação, é passível que ela seja incluída também como documento no sentido amplo e arquivístico.

As fontes informacionais, partindo da área da ciência da informação, extrapolam, a partir de Otlet, para uma análise mais abrangente. Após a segunda metade do século XX, a história da sociedade, de acordo com pontos de vista individuais, começou a ser analisada e a contrapor a história de sujeito de grande influência social. A historiadora Ângela de Castro Gomes (2004) descreve a correspondência como uma forma de comunicação e escrita de si, onde é feita uma troca de informações entre sujeitos, cabendo ao receptor a preservação do documento. Descreve ainda, que a memória individual tem seu valor, especialmente como documento histórico, em uma qualidade decorrente de uma nova concepção de verdade e não somente na cultura imposta aos indivíduos de sobreviver na memória dos "grandes personagens".

A abordagem ampliada sobre a construção do conhecimento histórico, com a mudança historiográfica baseada nas ideias da Escola dos Annales, com pensadores como Lucien Febvre, Marc Bloc, Fernand Braudel, Jacques Le Goff, entre outros, trataram das mudanças dos paradigmas referentes à construção do conhecimento histórico, permitiu que, através das novas linguagens (imagens, fotos, música, cartas, diários, vestimentas) os fatos e processos históricos fossem interpretados sob um novo prisma. Caracteriza-se assim a importância da construção e preservação de acervos com uma gama diversificada de documentos, tornando possível uma pesquisa mais abrangente e coerente referente a um fato ou período a ser analisado.

Partindo da conceituação de Otlet, Escolas dos Annales e Gomes, as cartas tornam-se fonte documental, sendo necessária sua salvaguarda, tratamento, disponibilização e recuperação da informação. Como apontado por Baumann (2011), o processamento técnico arquivístico possibilita a recuperação da informação e a acessibilidade de forma facilitada do documento, passando a ser a sua representação. Para isso, o arquivista necessita ter um conhecimento da terminologia e dos conceitos históricos. Jimerson (2008) descreve o profissional não somente como um facilitador do processo informacional, mas também um sujeito imprescindível no processo de preservação patrimonial e da memória social da seguinte forma:

O foco dos arquivistas no lado técnico de seus afazeres, por vezes, obscurece suas responsabilidades sociais e culturais. A ênfase demasiada em sistemas de gestão de documentos, accountability e provas - todas cruciais para arquivos institucionais poderia levar à negligência e desvalorização do nosso papel de preservar o patrimônio, a cultura e a memória social (JIMERSON, 2008, p. 38).

Múltiplos Olhares em Ciência da Informação, v.8, n.1, mar. 2018. 
Entre as responsabilidades do arquivista, uma análise sobre o estado do documento e a elaboração do processo de conservação é um fator de grande importância. Para isso, é necessário compreender os conceitos de preservação e conservação, assim definidos por Cassares (2000):

\footnotetext{
Preservação: é um conjunto de medidas e estratégias de ordem administrativa, política e operacional que contribuem direta ou indiretamente para a preservação da integridade dos materiais.

Conservação: é um conjunto de ações estabilizadoras que visam desacelerar o processo de degradação de documentos ou objetos, por meio de controle ambiental e de tratamentos específicos (higienização, reparos e acondicionamento).

Restauração: é um conjunto de medidas que objetivam a estabilização ou a reversão de danos físicos ou químicos adquiridos pelo documento ao longo do tempo e do uso, intervindo de modo a não comprometer sua integridade e seu caráter histórico (CASSARES, 2000, p.12).
}

Dentro da política de preservação será analisado os três fatores de aceleração da degradação do documento: agente físico, agente biológico e a ação humana. Com base em Cassares (2000), podemos descrevê-los como:

\section{- Agentes físicos:}

Iluminação: tanto a luz natural como a luz artificial emitem raios que prejudicam livros. A incidência de luz provoca danos irreversíveis e acumulativos ao papel, tornando-os frágeis, quebradiços e amarelados.

Temperatura/Umidade: o calor danifica os materiais e a umidade facilita a proliferação de fungos e de insetos.

Poluição atmosférica: a poeira e as demais partículas em suspensão que a compõem, se depositam sobre o acervo e aderem ao papel gerando sujidade e até alimentos para pragas, capazes de comprometer a integridade dos acervos documentais.

\section{- Agentes biológicos:}

São caracterizadas por fungos e bactérias, tais como: insetos (traças, baratas, cupins, brocas, piolhos de livros), e os roedores. As razões de sua presença em bibliotecas dependem do conforto ambiental promovido pela temperatura e umidade relativa elevada, pouca circulação de ar, falta de higiene, acesso a alimentos, entre outros. Além de nocivos ao acervo, muitas dessas pragas também são nocivas ao homem, contaminando o ambiente e colocando em risco sua saúde.

\section{- Ação humana}

Manipulação e armazenamento inadequada dos documentos e a falta de gerenciamento de riscos para as coleções. 
Claudia Carvalho (1998) destaca que na política de preservação especificamente sobre o suporte documental, papel, é necessário ainda levar em consideração o ambiente e a conservação do papel e que seja feito um controle ambiental da umidade, da radiação ultravioleta, da temperatura e exposição direta e indireta de luz, sendo assim possível uma conservação adequada do acervo. E ressalta ainda especificamente sobre o papel:

O papel é uma substância orgânica e, devido à sua fragilidade, está sujeito à deterioração, se for impropriamente produzido, armazenado ou manuseado. No entanto, sob condições adequadas, pode ter duração infinita. O ambiente é um dos principais agentes de deterioração do papel e o controle ambiental consiste na manutenção dos fatores climáticos dentro de níveis adequados, estáveis, durante 24 horas por dia, 365 dias por ano (CARVALHO, 1998, p.5).

É necessária uma maior urgência ao iniciar o processo de preservação no caso das cartas, pois estes acervos normalmente são de origem privada e não passam por processos adequados de conservação. Umas das opções para a conservação, diminuindo assim o manuseio dos originais, mas que também permitirá o acesso informacional dos documentos, é a digitalização, que vem ganhando espaço e sendo ampliada. Santos e Silveira (2015) apontam sobre a necessidade de observação de todas as questões que envolvem a preservação digital e o acompanhamento constante das novas tecnologias ligadas a área, que demandam ainda atenção para que, realmente as informações sejam preservadas neste novo formato, mas sem o descarte das fontes originais e também descrevem, por exemplo, a importância do processo de digitalização dos documentos como, de forma a permitir uma maior acessibilidade aos conteúdos dos documentos:

Muitos materiais especiais encontram-se fragilizados, impossibilitados de serem consultados manualmente, resultando em um movimento de ampla digitalização de seus suportes, a fim de disponibilizar o acesso a este conhecimento registrado. Desse modo, o acesso à informação existente no material histórico seria permitido quantas vezes fossem necessárias, sem danificar o suporte original (SANTOS; SILVEIRA, 2015, p. 2).

Porém, para digitalizar um acervo, é necessário averiguar se no conteúdo existe algo passível de direitos autorais. Caso tenha, é preciso a autorização dos sujeitos (emissor/receptor) se estiverem vivos e, em caso de falecimento, a autorização é feita por quem detém os direitos autorais, até o período de 70 anos, contados a partir da data de falecimento. Depois deste período, cai em domínio público, não havendo assim, restrição de uso de uma obra por qualquer um que queira utilizá-la, de acordo com a lei de direitos autorais, de acordo com o artigo 43, Lei 9.610 de 1998 (BRASIL,1998). 
Um acervo devidamente organizado é um facilitador ao acesso à informação para investigações feitas por diversos pesquisadores, tanto na sua forma de preservação, que lida com os componentes físicos desses documentos, quanto na investigação de seus conteúdos.

\section{FRANCISCO CURT LANGE}

Montero (1998) descreve a biografia do musicólogo Francisco Curt Lange, que na verdade foi batizado como Franz Kurt Lange. Nascido em 12 de dezembro de 1903, em Eilenburg (Alemanha), Kurt Lange faleceu em 3 de maio de 1997, em Montevidéu (Uruguai). Ainda na Alemanha, forma-se em Arquitetura pela Universidade de Munique e, posteriormente, desenvolve sua formação musical, na qual passou a se dedicar e a pesquisá-la. Em 1923, Lange se naturalizou uruguaio, alterando seu nome para Francisco Curt Lange, e mantendo laços naquele país pelo resto da vida. Em 1938, Lange foi o idealizador e co-fundador do Instituto Interamericano de Musicografia no Uruguai, onde trabalhou pela instauração de uma educação musical estável. O estudioso criou o Departamento de Musicologia na Universidade de Cuyo na Argentina, em 1948. Já no ano de 1958, tornou-se pesquisador da Unesco, mudando para Minas Gerais, Brasil, onde pesquisou sobre a música do período colonial brasileiro. Segundo Régis Duprat, em Minas Gerais, o trabalho de Lange:

Complementavam uma atividade singela e centenária das sociedades musicais até hoje existentes em muitas cidades mineiras, que por mais de dois séculos executavam tradicionalmente o repertório mais antigo, em sintonia com o calendário litúrgico católico, especialmente durante a Semana Santa. Os resultados das pesquisas de Curt Lange foram objeto de grande interesse por patê do público erudito e da alta cultura brasileira, que passou a valorizá-lo sendo, desde então, executado com frequência nas salas de concertos e registrado em considerável discografia (DUPRAT, 2010, p. 261).

Duprat (2010) e Cotta (2006) relatam que o legado de Curt Lange, atualmente, desperta o interesse de jovens pesquisadores para entender e aprofundar e, dessa maneira, tentar inferir, por meio dos documentos acumulados dos últimos 50 anos, sobre a Música na Capitania de Minas Gerais, o conjunto da obra e a abordagem histórica. Além do acervo Curt Lange localizado na Biblioteca Universitária da UFMG, parte do legado de Curt Lange encontra-se no Museu da Inconfidência em Ouro Preto, descrito como Coleção Curt Lange, com acesso ao público desde 1991.

Algumas das descobertas do musicólogo, conforme descrito por Duprat (2010), receberam homenagens e foram lançadas em CDs, como o "Spiritus Domine', de Francisco Gomes da Rocha, uma das peças que figuraram no CD Música do Brasil Colonial: compositores mineiros", 
bem como os "Motetos de Passos", inédito e de autor anônimo, editados por Curt Lange também fizeram parte deste $\mathrm{CD}$. Outras homenagens ao longo do tempo vão sendo realizadas em nome das pesquisas feitas por ele, que deram e darão frutos em prol da consagração da música mineira.

Duprat (2010) revela situações que Curt Lange enfrentou como "pioneiro da musicologia histórica no Brasil", como forma de fazer justiça a esse grande pesquisador. Entre elas, ele cita em suas viagens de investigação, não raro Curt Lange encontrar papéis de músicas amontoados, desprezados pelos herdeiros ou instituições, e até mesmo em vias de serem queimados ou despejados no lixo. Curt revelava que não via outra solução emergencial a não ser comprar esses papéis com recursos próprios de modo a evitar a destruição de acervos que ele sabia que seriam preciosos para a história da música no Brasil.

Isso revela a relação do pesquisador com sua pesquisa, que muitas vezes se tornava parte da vida do pesquisador de forma elementar. O trabalho do pesquisador nem sempre é reconhecido no momento da pesquisa, vindo a se tornar obras raras somente tempos mais tarde, rendendo diversas outras pesquisas para compreender questões de um certo momento histórico além de contribuir para o desdobramento de novas descobertas.

\section{O ACERVO CURT LANGE}

O musicólogo deixou um grande legado para a música brasileira, dedicando parte de sua vida à organização de seus objetos em forma de acervo, que conta com mais de cem mil documentos como correspondências, instrumentos musicais, livros, discos, publicações e artigos inéditos. No fim de sua vida, disponibilizou esse material para que fosse produzido um centro com seu acervo pessoal, com intuito de tornar acessíveis seus estudos, manuscritos e objetos pessoais como fontes de pesquisa ${ }^{4}$.

Em um projeto interdisciplinar, a Fundação de Desenvolvimento da Pesquisa (Fundep) gerenciou, sob a coordenação do musicólogo André Guerra Cotta e vários funcionários da UFMG, como profissionais da área da ciência da informação, arquitetos e restauradores, o processo de construção do espaço e forma de organização do pecúlio. As equipes trabalharam no acervo ao longo de uma década (de 1995 a 2005), período em que foi feita a descrição arquivística, utilizando a Norma Geral Internacional de Descrição Arquivística ISAD(G), padrões e normas internacionais possibilitando assim, a recuperação da informação (GUIA..., 2005, p. 40). Parte significativa deste acervo são as cartas do estudioso, que de acordo com Ana Lúcia

\footnotetext{
${ }^{4}$ Informação coletada em visita ao acervo e entrevista com a bibliotecária Diná Araújo.

Múltiplos Olhares em Ciência da Informação, v.8, n.1, mar. 2018.
} 
Almeida Gazzola, a essas cartas "devemos a reconstituição de inúmeras fontes primárias para a pesquisa musical no Brasil e na América Latina" (GAZZOLA, 2005, p. 14).

Para André Guerra Cotta, coordenador do projeto, o Guia Acervo Curt Lange é um primeiro meio de divulgação, resultado de um extenso trabalho. Além disso, uma versão trilíngue do Guia foi disponibilizada em partes na sua página na Web. Os esforços para a divulgação servirão para abranger as consultas, pesquisas e o ensino na área da música e da cultura latinoamericana. Além desse público específico, demais pesquisadores poderão fazer uso desses documentos devido ao seu vasto conteúdo informacional. Historiadores, antropólogos, literatos, estudiosos da ciência da informação, entre outros poderão, diante desse material, produzir novos conhecimentos (GUIA..., 2005, p. 22).

O acervo foi dividido em séries (GUIA..., 2005 ${ }^{5}$ ):

\footnotetext{
${ }^{5}$ Versão online do guia disponivel em: https://curtlange.lcc.ufmg.br/pguia_pgs/pguia05.htm.
}

Múltiplos Olhares em Ciência da Informação, v.8, n.1, mar. 2018. 
Série 1 - Coleção Bibliográfica

1.1 - Obras de Referência

1.2 - Monografias

1.3 - Periódicos

1.4 - Separatas

1.5 - Folhetos

1.6 - Libretos de Ópera

1.7 - Publicações Editadas por Curt Lange

Série 2 - Correspondência

2.1 - Correspondência Enviada

2.2 - Correspondência Recebida

Série 3 - Vida

Série 4 - Partituras

4.1 - Originais e Cópias de Manuscritos

Musicais

4.2 - Partituras Publicadas por Curt Lange

4.3 - Partituras Publicadas por Terceiros

Série 5 - Instrumentos Musicais

Série 6 - Instrumentos de Trabalho

6.1 - Equipamentos

6.2 - Manuais

Série 7 - Registros Audiovisuais

7.1 - Discos de Vinil

7.2 - Compact Disc

7.3 - Fitas Cassetes

7.4 - Fitas de Rolo

7.5 - Fitas de Vídeo

Série 8 - Iconografia

8.1 - Fotografias

8.2 - Quadros

8.3 - Slides e Microfilmes

8.4 - Imagens Diversas

8.5 - Negativos

Série 9 - Documentos Raros

9.1 - Obras Musicais

9.2 - Doc. Manuscritos de Arquivos

Históricos

Série 10 - Documentos de Pesquisa

10.1 - Biobibliografia

10.2 - Miscelânea

10.3 - Estudos e Transcrições

10.4 - Artigos e Originais Recebidos de

Pesquisadores

10.5 - Transcrições e Edições de Obras

Musicais

10.6 - Domenico Zipoli

Múltiplos Olhares em Ciência da Informação, v.8, n.1, mar. 2018.
10.7 - Originais e Avulsos de Curt Lange

10.8 - Inventários

10.9 - Excertos Musicais

10.10 - Recortes da Imprensa

Série 11 - Catálogos, Programas e

Similares

11.1 - Programas de Concertos, Festivais $\epsilon$

Eventos Musicais

11.2 - Catálogos e Folders

11.3 - Catálogos de Editoras e Gravadoras

11.4 - Atividades Realizadas por Lange

11.4.1 - Programas de Concertos

11.4.2 - Catálogos e Folders

11.4.3 - Catálogos de Editoras

Série 12 - Homenagens

Série 13 - Lembranças 
O material que já se encontrava em estado de degradação passou pelo tratamento de intervenção, de revitalização e conservação, permitindo assim o acesso ao público. Primeiramente, a estrutura física onde o acervo foi depositado também recebeu tratamento de prevenção, porém, mesmo assim, o espaço era inadequado. No ano de 2005, passou a ocupar uma sala especial no $4^{\circ}$ andar da Biblioteca Universitária da UFMG ${ }^{6}$. De acordo com Mário Sousa Júnior (2005, p. 20), a manutenção “do acervo priorizaram a limpeza, o acondicionamento e a guarda adequada dos documentos, considerando a especificidade e necessidade dos materiais, já que em sua grande maioria os materiais celulósicos apresentavam variados estágios de deterioração". Esse procedimento é essencial para a preservação de materiais efêmeros.

O foco deste artigo é a série "2 - Correspondência" do acervo Curt Lange, integrado ao acervo da Biblioteca Universitária da UFMG, no qual estão arquivadas as cartas, contendo cópias das cartas que o Curt Lange enviou (subsérie 2.1) e as originais recebidas (subsérie 2.2). Curt Lange trocava várias cartas com diversos intelectuais brasileiros. Dessa forma, ele concebeu um patrimônio de conteúdo informacional. A restauração e organização foi realizada para proporcionar a acessibilidade ao material. Por isso, Simone Aparecida dos Santos, à época diretora da Biblioteca Universitária, relatou:

É importante destacar o trabalho realizado pelo conservador Mário Sousa Júnior, orientando as atividades de conservação em um conjunto tão diversificado de suportes, assim como pioneiro da bibliotecária Marlene de Fátima Vieira Lopes na elaboração de metodologias para tratamento do material arquivístico. (SANTOS, 2005, p. 16)

O armazenamento inicial das cartas que fazem parte da série 2 do acervo Curt Lange era em pastas suspensas em arquivos de gaveta, uma forma inadequada, pois, a degradação do material é acelerada desta forma. O mobiliário antigo era considerado inadequado à conservação, mas constam anotações de Lange, e então foram expostos no acervo como fonte documental. Atualmente, as cartas estão acomodadas em caixas, uma parte delas foi encadernada pelo próprio musicólogo, que foram armazenadas e etiquetadas de acordo com a organização e identificação da classificação como descreve Mário Júnior (2007), que também detalha o processo de adequação da conservação da documentação:

Todo esse material foi higienizado sendo efetuadas também remoção de grampos metálicos, pequenos reparos em alguns itens que se encontravam fragilizados como também planificação daqueles que apresentavam deformações planares. Os documentos foram entrefolhados com papel Sulfite alcalino, 75 grs., em folhas tamanho A4 e A3 de

\footnotetext{
${ }^{6}$ Informação coletada em visita ao acervo e entrevista com a bibliotecária Diná Araújo. 
acordo com o tamanho e quantidades dos dossiês e documentos, substituindo assim as antigas pastas suspensas, barbantes e separadores. Est as medidas dos documentos medindo $34 \times 25 \times 6 \mathrm{~cm}, 38 \times 29 \times 4 \mathrm{~cm}$ e $45 \times 35 \times 4 \mathrm{~cm}$ em papel alcalino Supremo, 350 grs. e ausentes de cola, sendo a montagem efetuada somente por encaixes. Estas caixas foram etiquetadas conforme organização original das séries e em seguida acondicionadas no arquivo (JÚNIOR, 2007, p. 268).

A série 2 comporta as subséries "2.1 - Correspondências Enviadas", que conta com 58 mil cartas distribuídas em 186 dossiês, e "2.2 - Correspondências Recebidas", com 40.100 cartas divididas em 2.565. Essas epístolas estão relacionadas a praticamente toda a vida de Curt Lange e nelas se encontram o percurso biográfico tanto de Lange quanto de seus correspondentes que figuram entre a vida musical e outras artes de diversos países (GUIA..., 2005, p.47).

O conteúdo das cartas é diversificado. No período em que esteve em Minas Gerais fazendo suas pesquisas, Curt Lange trocou correspondências falando sobre as experiências e frustrações sobre a coleta das informações e documentos. Em visita ao acervo verificou-se que a série 2 é uma fonte informacional que abrange diversas áreas do conhecimento como: literatura, em suas conversas com Carlos Drummond de Andrade e Mário de Andrade; com o Maestro Lorenzo Fernández onde foram feitas trocas de informações sobre o Boletín Latino Americano de Música. Além de troca de informações com os renomados regentes: Juan Carlos Paz, Heitor Villa-Lobos.

Observando a diversidade informacional das cartas, percebe-se a importância da preservação destes arquivos, que permitem um maior contato com informações que possivelmente seriam perdidas, Salomon (2010) ainda destaca que as cartas podem ser também, agentes auxiliadores no resgate da memória brasileira. André Cotta (2006) descreve a relevância da série "2 - Correspondência" do acervo de cartas de Curt Lange, como fonte informacional:

Embora possa parecer um tanto personalista, a ação de preservar tal documentação e, sobretudo, de disponibilizá-la para a pesquisa, consiste em gesto de grande generosidade, uma vez que, ao trazer reunida e organizada toda uma série completa de correspondência trocada entre ele e milhares de indivíduos em países diversos, resolve para as futuras gerações sérios problemas heurísticos (COTTA, 2006, p.7).

Ao longo do trabalho e levantamento de informações sobre o acervo de Curt Lange, feitos através de pesquisas diretas ao acervo e por meio de entrevista com funcionários da BUUFMG, pode-se observar que há um crescente interesse sobre suas obras e seu acervo geral, não somente na área da musicologia, mas abrangendo também as diversas questões relativas ao seu tempo e cotidiano, tornando de grande valia a conservação e preservação de seus objetos, partituras, manuscritos e cartas.

Múltiplos Olhares em Ciência da Informação, v.8, n.1, mar. 2018. 


\section{CONSIDERAÇÕES FINAIS}

A história de uma sociedade não é composta somente por documentos oficiais. Partindo desta premissa, este artigo levantou o debate da carta como documento e fonte informacional, não somente para estudos biográficos. A preservação dessa memória vem sendo discutida no meio acadêmico, desde os profissionais de história, perpassando a Arquivologia, a Biblioteconomia e a Museologia. Por serem suportes informacionais únicos e de grande valor histórico, é imprescindível a preservação deste suporte de memória sociocultural.

No âmbito do processo de preservação do documento físico destaca-se a característica da composição material. A fragilidade do papel dificulta o manuseio, porém, constata-se a grande importância do objeto de estudo e fonte informacional. É de responsabilidade dos profissionais da ciência da informação criarem as políticas de preservação, conservação e ainda serem facilitadores de acesso aos seus conteúdos e na recuperação de suas informações.

Em relação ao acervo Curt Lange, considera-se que há muito a ser pesquisado sobre esse legado, mesmo se tratando de um acervo fragmentado, pois contém elementos na Biblioteca Nacional da Venezuela, Biblioteca Universitária da UFMG e no Museu Inconfidência em Ouro Preto. O acervo exposto na BU possui um volume rico e diversificado de seus documentos e objetos pessoas. E a série 2 correspondência do acervo é um grande acervo de cartas, onde em seu conteúdo há temáticas das artes, cultura e política o que o torna uma fonte informacional próspero.

\section{REFERÊNCIAS}

ARAÚJO, Diná Marques Pereira. Belo Horizonte, 10 ago. 2017. Entrevista concedida a Nicole Marinho Horta.

ARQUIVO NACIONAL. (Brasil). Dicionário Brasileiro de Terminologia Arquivística. Rio de Janeiro: Arquivo Nacional, 2005.

BAUMANN, Eneida Santana. O Arquivo da Família Calmon à Luz da Arquivologia

Contemporânea. Salvador, 2011. Dissertação (Mestrado em Ciência da Informação). Programa de Pós-Graduação em Ciência da Informação da Universidade Federal da Bahia, 2011.

BRASIL. Congresso Nacional. Lei n 9.610, de 19 de fevereiro de 1998. Altera, atualiza e consolida a legislação sobre direitos autorais e dá outras providências. Diário Oficial da União, Poder Executivo, Brasília, DF, 20 fev. 1998. Seção 1. p. 3. Disponível em: <http://www2.camara.leg.br/legin/fed/lei/1998/lei-9610-19-fevereiro-1998-365399-normapl.html>. Acesso em: 10 ago. 2017. 
BURKE, Peter. A escola dos Annales (1929-1989): a revolução francesa da historiografia. São Paulo: UNESP, 1990. 176 p.

CARVALHO, Claudia S. Rodrigues de. O espaço como elemento de preservação dos acervos com suporte em papel. Rio de Janeiro: Academia Brasileira de Letras, Centro de Memória, 1998. 44 p.

CASSARES, Norma Cianflone. Como fazer conservação preventiva em arquivos e

bibliotecas. Colaboração de Claúdia Moi. São Paulo: Arquivo do Estado/ imprensa oficial, 2000. $80 \mathrm{p}$.

CHARTIER, Roger (org). História da vida privada, 3: da renascença ao Século da Luzes. Trad. Hildegard Feist. São Paulo: Cia. das Letras, 1991. p.211-219.

COTTA, André Guerra. Correspondência pessoal como fonte histórica e musicológica. Caderno do Colóquio. UNIRIO, v. 8, n. 1. 2006. Disponível em:

<http://www.seer.unirio.br/index.php/coloquio/article/view/132/93> Acesso em: 11 ago. 2017.

COTTA, André Guerra(org). Guia Acervo Curt Lange. Belo Horizonte: Editora UFMG, 2005. $96 \mathrm{p}$.

DUPRAT, Régis. O legado de Francisco Curt Lange (1903- 1997). Revista Brasileira de Música. Universidade Federal do Rio de Janeiro, v 23/2, 2010. Disponível em:

<http://rbm.musica.ufrj.br/edicoes/rbm23-2/rbm23-2-memoria.pdf> Acesso em: 10 ago. 2017.

FRANÇA, Júnia Lessa; VASCONCELLOS, Ana Cristina de. Manual para Normalização de Publicações Técnico Científicas. 9 ed. Belo Horizonte: Editora UFMG, 2013. 263 p.

GOMES, Angela de Castro (org). Escrita de si, escrita da história. Rio de Janeiro: FGV, 2004. $378 \mathrm{p}$.

GOMES, Eduardo de Castro. A escrita na História da humanidade. Revista Dialógica.

Universidade Federal do Amazonas, v.1, n. 3, p. 1-17. 2007. Disponível em:

$<$ http://cefort.ufam.edu.br/dialogica/files/no3/Vol03-03-

a\%20escrita\%20Historia\%20humanidade.pdf>. Acesso em: 11 ago. 2017.

MALATIAN, T. Narrador, registro e arquivo. In: PINSKY, Carla Bassanezi; LUCA, Regina de. (orgs). O historiador e suas fontes. São Paulo: Contexto, 2009. p. 195-222

MERRILL-OLDHAM, Jan; SCOTT, Jutta Reed. Programa de planejamento de preservação: um manual para auto instrução de bibliotecas. Rio de Janeiro: Projeto Conservação Preventiva em Bibliotecas e Arquivos; Arquivo Nacional, 2001. (Caderno Técnico, 37).

MONTERO, Luis Merino. Francisco Curt Lange (1903-1997): tributo a un americanista de excepción. Revista Musical Chilena, Santiago. v.52, n.189. 1998. Disponível em:<http://dx.doi.org/10.4067/S0716-27901998018900002>. Acesso em: 11 ago. 2017. 
NAGEL, Rolf. Dicionário de Termos Arquivísticos (Subsídios para uma terminologia arquivística brasileira). Salvador: UFBA, 1989.

OTLET, Paul. Documentos e documentação. Disponível em:

<http://www.conexaorio.com/biti/otlet/>. Acesso em: 12 ago. 2017.

SALOMON, Marlon. As correspondências: uma história das cartas e das práticas de escrita do Vale do Itajaí. Florianópolis: Ed. UFSC, 2002. 103 p.

SALOMON, Marlon. Arquivologia das correspondências. Rio de Janeiro: Forense Universitária, 2010. 56 p.

SANTOS, Luciana de Souza dos; SILVEIRA, Naira Christofoletti. A representação documentária de coleções especiais: breves considerações sobre os acervos do Rio de Janeiro. Disponível em:

<http://www.brapci.inf.br/index.php/article/view/0000017627/3e70f60d973a1f7fc2a48455cbaac a4f/> Acesso em 11 ago. 2017

SCHÄFER, Murilo Billig. FLORES, Daniel. Preservação da informação arquivística digital: repercussões para o patrimônio cultural. Revista da Faculdade de Biblioteconomia e Comunicação da UFRGS, Porto Alegre, v. 19, n.1, p. 173-186, jan./jun. 2013.

SCHELLENBERG, Theodore R. Arquivos modernos: princípios e técnicas. $6^{\text {a }}$ edição. Rio de Janeiro: Editora FGV, 2006. 386 p.

SOUZA JÚNIOR, Mário Anacleto. Conservação do acervo Curt Lange Biblioteca Universitária da UFMG. Revista Brasileira de Arqueometria, Restauração e Conservação - ARC. Olinda. v.1, n.5, p. 265-270. 2006. Disponível

em:<http://www.restaurabr.org/siterestaurabr/volumesarc/arc05pdf/10_MarioAnacleto.pdf >. Acesso em: 10 ago. 2017.

TANUS, G. F. S. C; RENAU, L. V.; ARAÚJO, C. A. A. O Conceito de Documento em Arquivologia, Biblioteconomia e Museologia. Revista Brasileira de Biblioteconomia e Documentação, São Paulo, v.8, n.2, p. 158-174, jul./dez. 2012. Disponível em:

<https://rbbd.febab.org.br/rbbd/article/viewFile/220/234>. Acesso em: 04 out. 2017. 